\title{
Causewayed enclosures in Ukraine? A new look at an Early Bronze Age site on the Ukrainian Steppe
}

Simon Radchenko ${ }^{1, *} \&$ Oleg Tuboltsev ${ }^{2}$

Recent fieldwork on the river island of Khortitsa has revealed what may be the first-known causewayed enclosure in Ukraine.

Keywords: Europe, Ukraine, Early Bronze Age, GIS, causewayed enclosure

Causewayed enclosures are well known across Europe, with many located in Germany, Denmark, Portugal and the UK (Hedges et al. 1978; Andersen 2004; Meyer \& Raetzel-Fabian 2006; Valera 2008). Relatively few are in Eastern Europe and none were previously known in Ukraine. Recent fieldwork on the island of Khortitsa, however, has identified the site of Generalka 2 as a causewayed enclosure (Tuboltsev \& Radchenko 2018). This discovery expands the geographic range of causewayed enclosures to the Ukrainian Steppes, and raises the question of whether there may be more of these sites even farther east.

The discovery of Generalka 2 leads us to believe that the absence of causewayed enclosures in Ukraine may be a result of difficulties in identifying these sites. Unlike Germany, Poland or Hungary (Tomas \& Javorski 2013), aerial photogrammetry has not yet been used to identify causewayed enclosures in Ukraine. The process of site identification is also hampered by the similarity between the natural soil and the fill of the ditches, making it very difficult to distinguish between the two. Consequently, identifying a site demands a commitment to long-term research.

Generalka 2 is on the island of Khortitsa, the biggest river island in Europe (Figure 1), located in the River Dnieper. It lies on a small (0.7ha) subtriangular promontory, formed by the high riverbank and a steep ravine (Figure 2). The site is separated from other parts of the island by segmented ditches that create a curvilinear barrier (Figure 3.1) and consists of two cultural levels that belong to the Early Bronze Age. According to faunal remains and the ceramic assemblage discovered in what seem to be floor levels, the upper level appears to be a settlement (Kaiser 2010). Samples of cattle bone used for radiocarbon analysis returned a date of 4190 \pm 35 BP (Poz-67457: 2817-2666 BC at 95.4\% confidence; date modelled in OxCal v.4.2.3 using IntCal13 calibration curve; Bronk Ramsey 2009; Reimer et al. 2013); this suggests that the site belongs to the Yamnaya culture.

The lower level is dated by a cattle bone to $4326 \pm 28$ BP (OxA-23080: 3086-2907 BC at 95.4\% confidence; date modelled in $\mathrm{OxCal}$ v.4.2.3 using IntCal13 calibration curve; Bronk

1 New Archaeological School, NGO, 2 Ernsta Street, Kyiv 03048, Ukraine

2 Department of Historical, Archaeological and Nature Sites Protection, National Reserve of Khortytsia, 9 Starogo redutu Street, Zaporizhzhya 69017, Ukraine

* Author for correspondence (Email: simon.radchenko@gmail.com)

(C) Antiquity Publications Ltd, 2019

ANTIQUITY 93 369, e18 (2019): 1-7

https://doi.org/10.15184/aqy.2019.53 


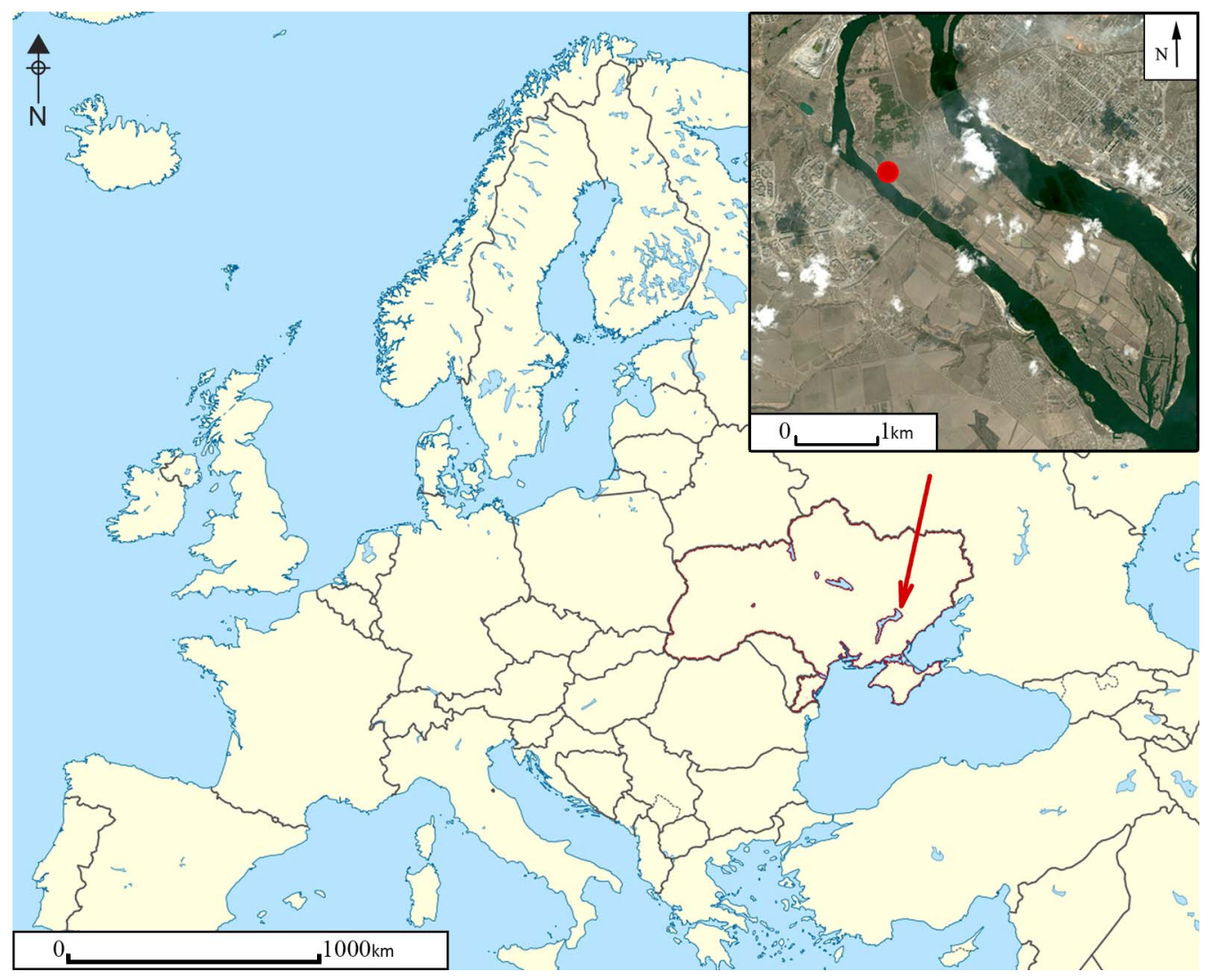

Figure 1. Location map (figure by Simon Radchenko).

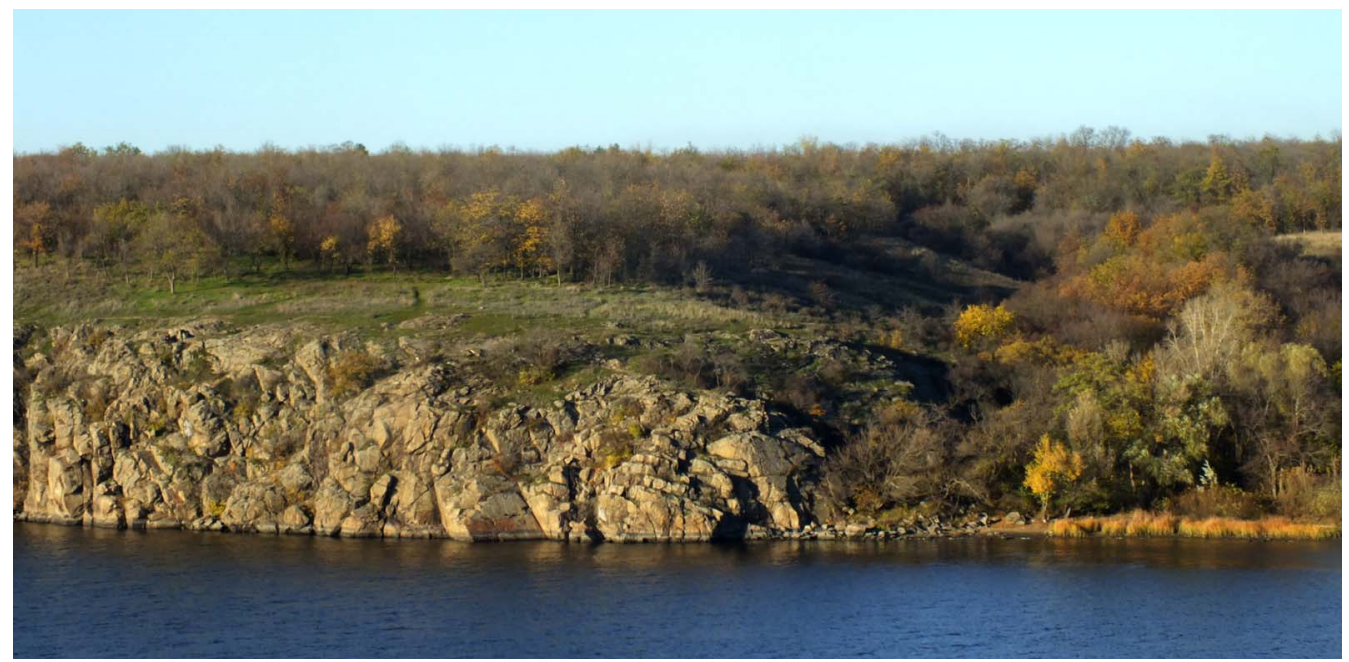

Figure 2. The site of Generalka 2 as viewed from the west (photograph by Oleg Tuboltsev).

(C) Antiquity Publications Ltd, 2019 


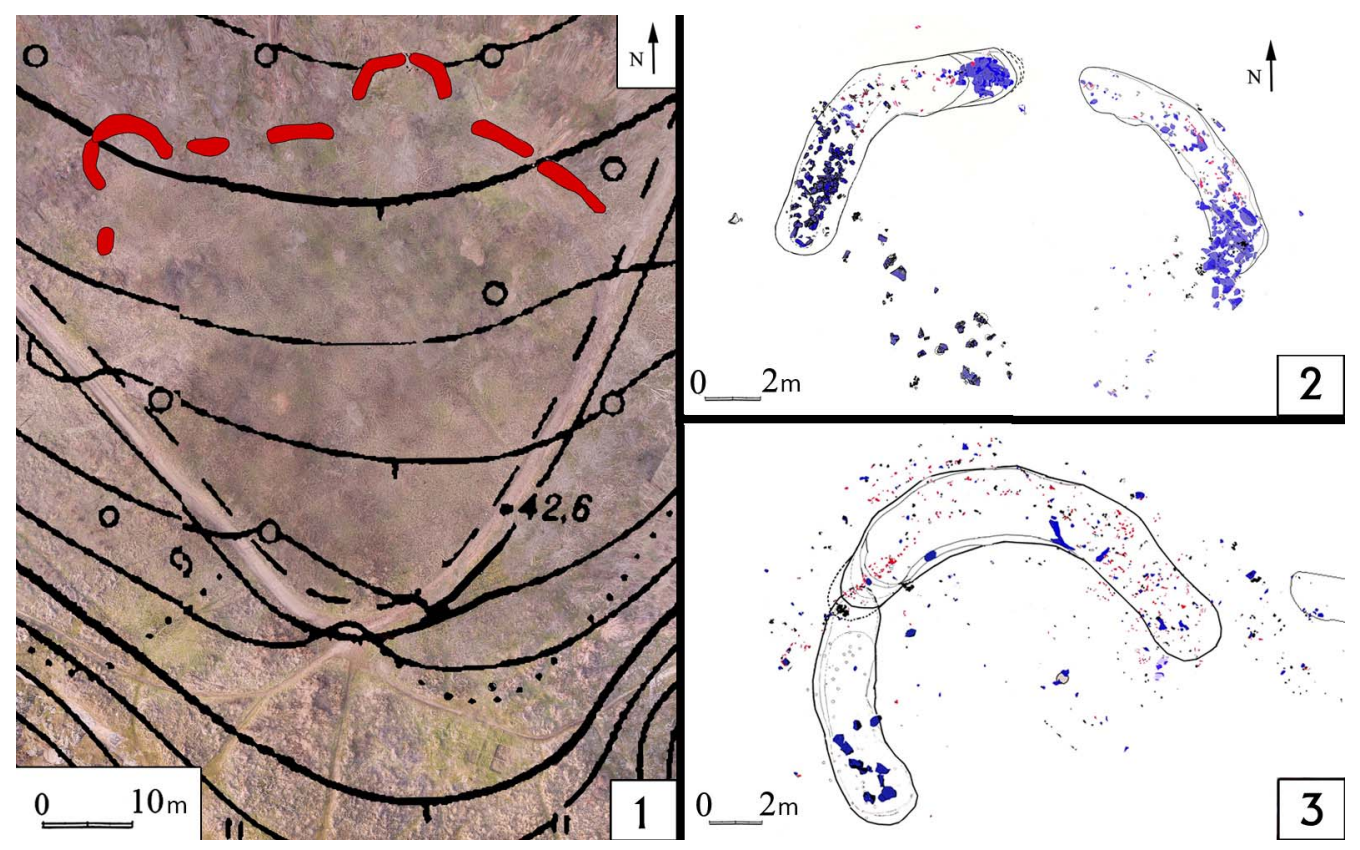

Figure 3. The island promontory showing the location of ditches that form the curvilinear barrier: 1) general layout of the site; 2) northern semi-rondell; 3) north-western semi-rondell (figure by Oleg Tuboltsev).

Ramsey 2009; Reimer et al. 2013). Finds in this level are concentrated close to, and in the fill of, the ditches; most were near the bottom and seemed to be structural deposition. The ditches enclosing the site appear contemporaneous with this phase of use; they include semirondells (semi-circular segments) formed by two overlapping cuts, with the former oriented to the north and north-west (Figure 3). About 60 postholes were also discovered within the ditches and following their contour. As with those at Western European causewayed enclosures (Harris 2003; Pollard 2012), the ditches contained significant objects including a human skull, pebbles and a sacrificial stone, which indicate a ritual function for the site.

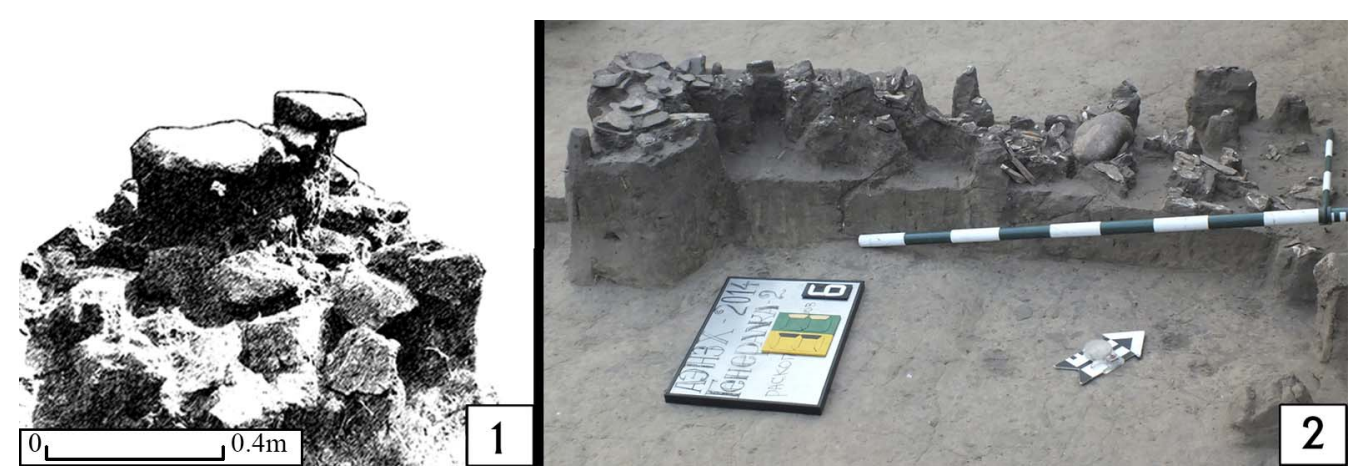

Figure 4. The sacrificial stone (left) and the finds assemblage at the bottom of the north-western semi-rondell (right) (figure by Oleg Tuboltsev).

(C) Antiquity Publications Ltd, 2019 


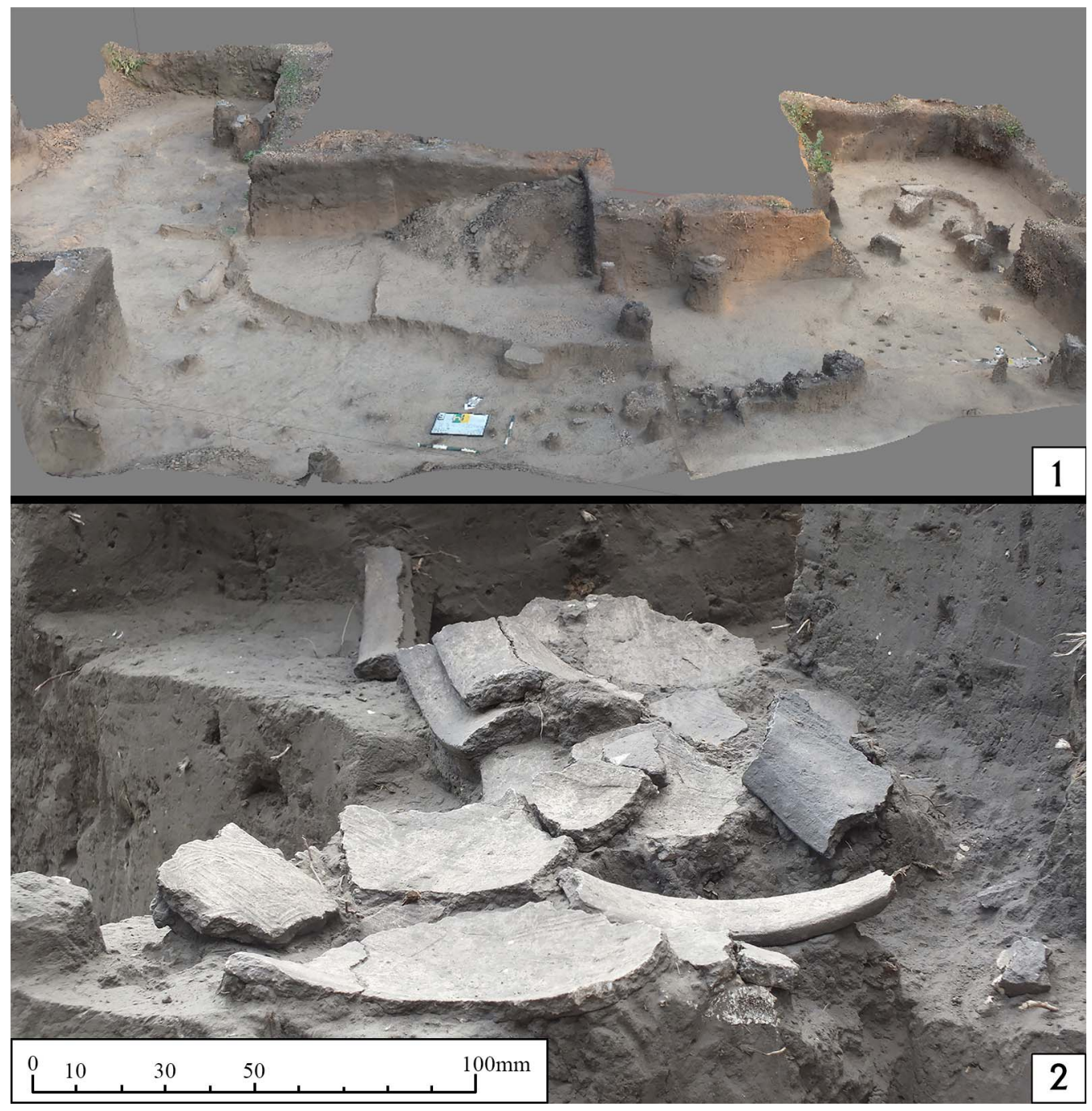

Figure 5. 1) $3 D$ model of the excavated north-western semi-rondell; 2) detail of the two ceramic vessels found in situ (figure by Simon Radchenko).

The ceramic assemblage includes more than 170 vessels that fall into one of two broad groups reflecting the two phases of the site (Tuboltsev \& Radchenko 2018: 129, fig. 9). The ceramics associated with the lower layer are mostly close to or within the ditches, while those associated with the later level are distributed across the site.

Significant finds, such as a jawbone and a sacrificial stone, appear to concentrate at the intersections of the semi-rondell segments (the northernmost and north-westernmost points of the site). Deposits of stone were found in the northern semi-rondell ditches and on their surface; the 'sacrificial stone' and a fragment of human jaw were located at the northern point of this semi-rondell (Figure 4). Cattle bones (mostly ribs) were concentrated at the bottom of the north-western semi-rondell; at the bottom edge of the ditch was an assemblage including a large pebble, bones and two broken ceramic vessels (Figure 4).

(C) Antiquity Publications Ltd, 2019 


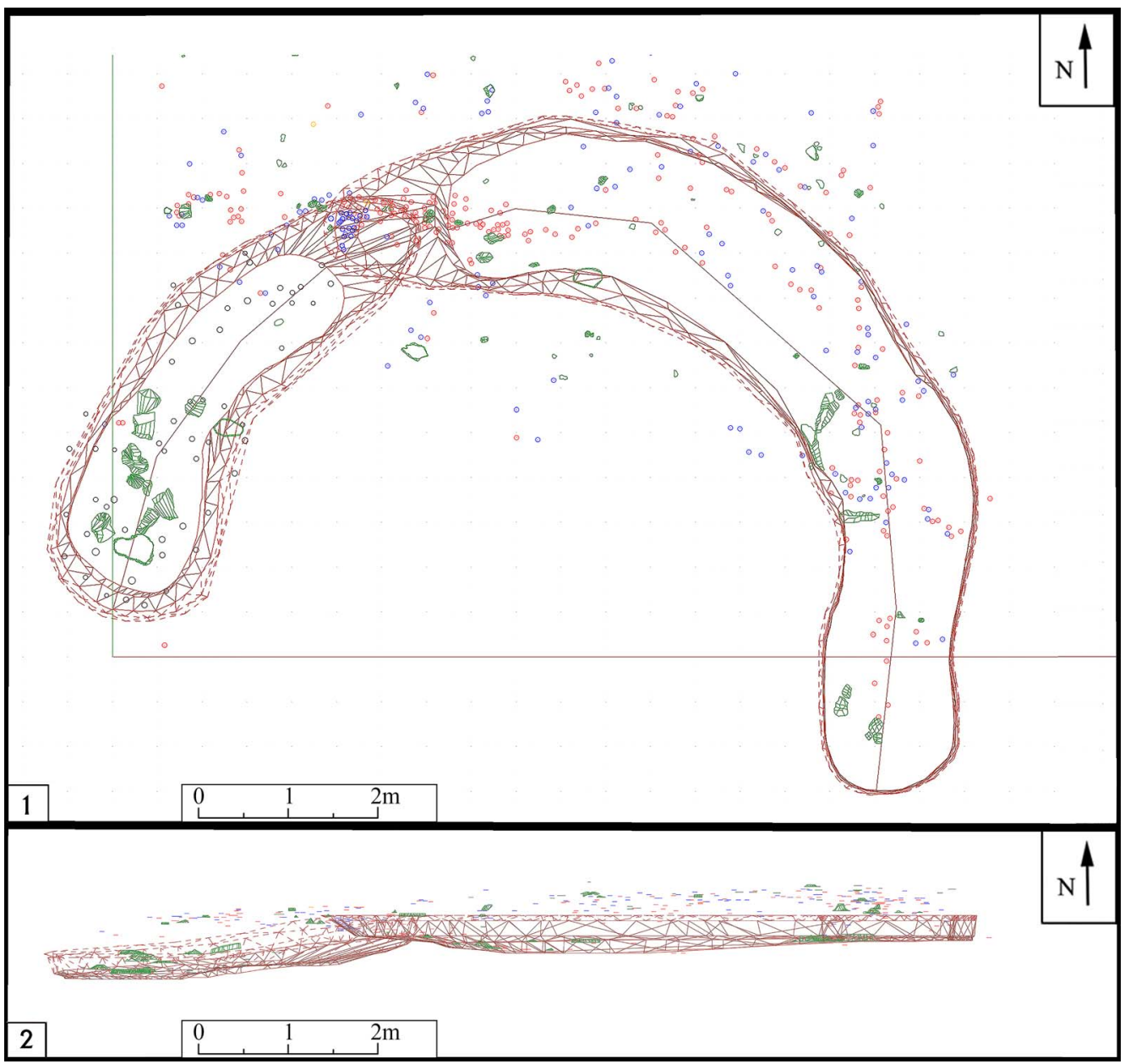

Figure 6. 3D GIS-model of the north-western semi-rondell, showing that the ditches were originally separate and then later recut to overlap: 1) plan; 2) profile (figure by Simon Radchenko).

Interpretation of Generalka 2 is fraught with stratigraphic difficulties. The fill of ditches is very similar to the natural chernozem and plagued by burrowing activity, which complicates the process of interpretation. The shape and upper contours of the ditches cannot therefore be easily identified, and are reconstructed from numerous stratigraphic profiles and GIS mapping; this is time-consuming. A 3D model of the northwestern semi-rondell (Figure 5.1) reconstructs the shape of the ditches and shows the location of the finds assemblage (Figure 5.2). Numerous postholes indicate the existence of palisade.

A 3D GIS model also reveals that while U-shaped ditch segments were separate at their deepest point, they overlapped one another at surface level, creating the semi-circular ditch feature (Figure 6). Two ceramic vessels were located at the point of this overlapping (Figure 5.2), which is also the north-westernmost point of the site.

(C) Antiquity Publications Ltd, 2019 
The same phenomenon can be seen in the northern semi-rondell. The distance between ditch segments in the semi-circular ditches is much shorter than between the straight ditches. This forces us to reconsider the idea that semi-rondells were used as entrances to a special area. Instead, entranceways were presumably located between the straight ditch segments.

Generalka 2 shares many similarities with European causewayed enclosures: areas delineated by segmented ditches; astronomical orientation of some ditch elements; the ritual character of finds; the landscape and its topography. All are aspects associated with causewayed enclosures in Western Europe (Whittle 1996; Harris 2003). This is compelling evidence that the Gerneralka 2 site is the first-known causewayed enclosure in Ukraine and, with the exception of sites in the Caucasian mountains (Belinskii et al. 2012), the easternmost in Europe. Although sites with interrupted ditches are well known in Ukrainefrom Trypillian sites such as Maidanetske, Nebelivka or Kamyane Zavallia 1 (Saile et al. 2016) - Generalka 2 differs in several key ways: the site is smaller; it has clear ritual associations; there is relatively little material culture, and what finds there are can be seen as structured deposits within the ditches. There is also a clear distinction between the Trypillian farmers from the western and central Ukraine and the Yamnaya culture at Gernalka 2.

The fact that Generalka 2 was only understood after highly detailed stratigraphic recording, long-term excavations and use of GIS technologies highlights the problematic nature of identifying causewayed enclosure sites in Eastern Europe. It is probable that the dearth of known causewayed enclosures in Ukraine is due to the difficulties in identifying the complexities of sites in this region and the lack of similar interpretations of ditch chronologies. The Generalka 2 study offers a new methodology for investigating well-known Early Neolithic and Bronze Age sites in Ukraine, such as Molyukhiv Bugor (Neradenko 2009). The complete excavation of Generalka 2 is a long-term project that has only just begun, but will continue to reveal aspects of the site in the future.

\section{References}

Andersen, N.H. 2004. Sarup. Causewayed enclosures placed in a Neolithic ritual landscape of Funen, Denmark. Journal of Nordic Archaeological Science 14: 11-17.

Belinskit, A.V., I. Fassbinder \& S. Reinhold. 2012. Zagadochnyie drevnie koltsevyie sooruzheniya severnogo Kavkaza i evropeyskie paralleli, in M.S. Gadzhiev, L.B. Gmyria \& R.G. Magomedov (ed.) The latest archaeological discoveries in the North Caucasus: research \& interpretations. The XXVII th Krupniv's readings: 29-31. Makhachkala: Мавраевь.

Bronk Ramsey, C. 2009. Bayesian analysis of radiocarbon dates. Radiocarbon 51: 337-60. https://doi.org/10.1017/S0033822200033865

Harris, O. 2003. Performative practice: identity and agency at the causewayed enclosures of Windmill

(C) Antiquity Publications Ltd, 2019
Hill and Etton. Unpublished MA dissertation, University of Cardiff.

Hedges, J., D. Buckley, C. Bonsall, I. Kinnes, J. Barrett, P. Drury, M.C. Wadhams, C. Cartwright, R.N.L.B. Hubbard, J. Evans \& A. Wilkinson. 1978. Excavations at a Neolithic causewayed enclosure, Orsett, Essex, 1975. Proceedings of the Prehistoric Society 44: 219-308. https://doi.org/10.1017/S0079497X0001015X

KaISER, E. 2010. Der Übergang zur Rinderzucht im nördlichen Schwarzmeerraum. Godisnjakjarhbuch 39: 23-35.

Meyer, M. \& D. Raetzel-Fabian. 2006. Neolithische Grabenwerke in Mitteleuropa. Ein Überblick. Journal of Neolithic Archaeology 8: 1-54.

Neradenko, T.N. 2009. Mogilnik Molyuhiv Bugor. Proceedings and Research in the Archaeology of Eastern Ukraine 9: 91-97 (in Ukrainian).

PolLARD, J. 2012. Living with sacred spaces: the henge monuments of Wessex, in A. Gibson 
(ed.) Enclosing the Neolithic. Recent studies in Britain and Europe: 93-107. Oxford:

Archaeopress.

Reimer, P.J. et al. 2013. IntCal13 and Marine13 radiocarbon age calibration curves $0-50000$ years cal BP. Radiocarbon 55: 1869-87. https://doi.org/10.2458/azu_js_rc.55.16947

Saile, T., M. Posselt, M. Dębieç, D. Kiosak \& T. Ткасник. 2016. Zwei Magnetometerprospektionen auf ukrainischen Fundstellen des Cucuteni-Tripolje-Komplexes an Dnjestr und südlichem Bug. Archäologisches Korrespondenzblatt 46: 465-77.

Tomas, A. \& M. JaworsKi. 2013. Non-destructive archaeological investigations in the Sarviz River valley (Hungary), 2012, in W. Godliewski (ed.) Swiatowit. Annual of the Insitute of Archaeology of the University of Warsaw X: 171-74. Warsaw: Institut Archeologii.

Tuboltsev, O. \& S. Radchenko. 2018. Generalka 2 and causewayed enclosures: examples of the polar worldview reflection of ancient Europe population. Stratum Plus 2018: 119-48.

Valera, A.C. 2008. Recinto calcolítico dos Perdigóes: fossos e fossas do Sector I. Apontamentos de Arqueologia e Património 3: 19-27.

Whittle, A. 1996. Europe in the Neolithic: the creation of new worlds. Cambridge: Cambridge University Press.

Received: 10 December 2018; Revised: 23 January 2019; Accepted: 26 February 2019 